\title{
Find the Courage to Face the World
}

\author{
Mei Liao and Zian Li
}

\section{Interview with Miss Zengzeng Zhao's Mother}

Zengzeng Zhao, female, born in 1988. Has a younger sister. Has Down Syndrome and Grade I intellectual disability. Graduated from a special school—Shanghai Zhabei Intellectual Development School. Image Ambassador for the 2007 Special Olympics World Summer Games held in Shanghai, and Outstanding Special Olympics Athlete in China from 2006 to 2010. Started working at Shanghai Papa John's in 2009.

Interviewee: Ms. Yi Zeng (Zengzeng Zhao's mother)

Interviewers and writers: Mei Liao, Zian Li

Interview date: July 1 and September 23, 2016

Interview place: Zengzeng Zhao's home.

\section{A Child from a Previous Life}

Q: Did you have kids as soon as you got married?

Zhao's mother: Yes. I was originally from outside Shanghai and moved to Shanghai in 1987 when I got married. Zengzeng was born in 1988.

Q: We read in the news about how you named your kids. Sounds like you and your husband really loved each other.

Zhao's mother: Yes, we did. When you put together the first names of the two kids, you get my name. My husband was a super nice guy, and we both love the kids very much.

M. Liao (凶)

Shanghai Shida Public Welfare Foundation, 29F, 999 Middle Huaihai Ro, Shanghai 200031, China

Z. Li

Shanghai Foreign Language School, 295 Zhongshan Bei Yi Ro, Shanghai 200083, China

(C) The Author(s) 2020 
Q: When she was first born, did you realize...

Zhao's mother: She was born healthy. A fair-skinned and chubby baby. There are pictures online of Zengzeng when she was young. She looked like any other kid. You couldn't see anything different about her.

Zengzeng did start walking later than other kids her age. Actually, she still couldn't walk by age two, but we never wondered, "Why can't she walk?" Nowadays a lot of kids can't walk at age two and their parents won't imagine the worst. While she was alive, my mom told me that it's okay if the child starts walking late, because some kids develop early and some develop late.

Her dad had a friend working as a doctor at Shanghai No. 1 People's Hospital. After Zengzeng turned two, we were having dinner at his place during Chinese New Year and he told us, "Your child might have some..." He couldn't go into the details because my husband was almost 40 when we had Zengzeng and she was very precious to him. So this friend said, "When you get a chance, bring your daughter to our hospital. Since we are friends, I will give her the check-up myself."

The check-up was very thorough and painful for Zengzeng. She was crying her lungs out and her dad almost stopped the check-up because he couldn't bear to see her that way. But I insisted on doing it. If there was anything wrong with my child, we had to be mentally prepared to educate and guide her. If it turned out that she was all normal, we'd of course educate and guide her as we would any other kid without disability.

The check-up results came out, which the doctor just told us instead of writing them on the medical record. He said that Zengzeng is slower than smart people but smarter than those who are really slow. I asked whether she could ever be independent, because I wouldn't want anything else from her. As long as she could be independent, I would be patient in teaching and guiding her. The doctor said she could learn to take care of herself. I felt better hearing that. Zengzeng was just delayed developmentally.

Q: Is Zengzeng's condition hereditary?

Zhao's mother: I must have won the lottery. My husband and I have no blood relation. The doctor said that the chance of having a child like Zengzeng was one in ten thousand. ${ }^{1}$ There's no family history on either my side or my husband's side, no such genes. So it's like I had hit the jackpot. I just couldn't figure it out. I was in good health. When I was 7 months pregnant with Zengzeng, I fell down the stairs at the old house but she managed to hang on in my tummy. Maybe she is my child from a previous life and has come to meet me in this life.

Q: How did the family feel about the diagnosis?

Zhao's mother: I was so very sad. Zengzeng was the apple of her dad's eye. Her dad's side of the family suggested that we give her away... abandon her. You know, there are definitely kids like her who get abandoned. Her dad said, "There's no way I am abandoning her. You carried her full term, she is our child." If we had really abandoned her, she might have ended up in the wrong hands and come to a worse

\footnotetext{
${ }^{11}$ Medical literature differs on the incidence of Down Syndrome. The rate is around 1/1500-1/3000 for expecting mothers in their $20 \mathrm{~s}, 1 / 300-1 / 900$ for expecting mothers in their $30 \mathrm{~s}, 1 / 100-1 / 130$ for expecting mothers around 39 , and 1/30-1/40 for expecting mothers around 45 .
} 
fate. So it's better to keep her with us. As long as we are alive ourselves, we will guide her. So I decided that I would raise my own child, whatever her condition.

Q: So how did you guide the child?

Zhao's mother: I did research, read books, and consulted other people. Kids like Zengzeng, they have a bad temper when they are young, throw tantrums all the time, and get out of control at home. But I had no choice. Just like her dad said, she is our child, so I needed to be patient educating her. When her dad had time off, every Saturday and Sunday, we would take her to the park. She has been to all the parks across Shanghai where we walked and played with her.

Before Zengzeng started working and before we realized her condition, my younger daughter was born. Having a younger one is a blessing, because she would play with Zengzeng and keep her company. Even now, my younger one is very nice and caring towards Zengzeng. She would come home and joke with Zengzeng and mess around with her. So Zengzeng is lucky to be in our family. She has a younger sister, whereas a lot of kids have no siblings.

Q: When Zengzeng was two or three, she couldn't walk well. Was there anything else that was different about her?

Zhao's mother: No other apparent differences. She just walked slow and threw tantrums sometimes. At first we didn't know she had Down Syndrome because medical science wasn't that advanced yet. Then China succeeded with the research and started naming kids like Zengzeng as Down babies. ${ }^{2}$ When Zengzeng was ten, her dad passed away. I was left alone with the two girls and had to work to support them. I hadn't known about that medical term.

Q: How did you teach her before she started school?

Zhao's mother: I bought a lot of toys and taught her at home, like "1-2-3", "Dad and Mom", reading cards, and poker cards. She still plays poker and board games even now, when she stays home on her days off.

Q: What did you do with the poker cards?

Zhao's mother: Her dad would pick a "2" and ask her to pick a "2" as well, that's how she learned numbers. We also used other cards to teach her reading, like "mom", "dad", "younger sister", "uncle" and "auntie".

Q: So she can read?

Zhao's mother: Yes, she can. She already knew "dad", "mom”, "younger sister" and "older sister" by the time she started school. Back then, we taught her daddy's name and mommy's name, and she could recognize them all. But she wasn't good at writing. Kids like her write really slowly. So I had to hold her hand to teach her, the way you teach kids when they first start elementary school.

$\mathrm{Q}$ : When did you start teaching her to write?

Zhao's mother: Her dad was already sick at that time, so he stayed home and taught her. She was about eight or nine. Her reactions were slow, so it wasn't easy to teach her. Other kids would have got it faster. It took a couple of weeks just to

\footnotetext{
${ }^{21}$ Down Syndrome was originally named "mongoloid" or "innate imbecility." In 1965, WHO officially changed the name to "Down Syndrome." In China, in as early as the 1960s, there were geneticists reporting on the trisomy 21 found in children with Down Syndrome.
} 
teach her "1", because she would forget as soon as we taught her. When she was in a good mood, she would want to learn. When she was in a bad mood, she would tell us "No". She liked to play and was always holding her toys and playing with them by herself.

Q: What toys did she like to play with?

Zhao's mother: She liked blocks and really liked building blocks. Her dad bought all her blocks and the blocks had numbers like 1, 2, 3 on them. Back then I wasn't working, so I took care of her at home and played building blocks with her.

Q: You went to great lengths to educate her.

Zhao's mother: Yes, we did. Bringing up two kids has not been easy. Looking back now, I still get teary from time to time. If I had to go through it all again, I would probably collapse. I tell my younger one that I don't even know how I have survived. I moved to Shanghai for marriage, without any relatives here. I am where I am today because I didn't give up.

\section{Sad Departure of Dad}

Q: Was Zengzeng heart-broken when her dad passed away?

Zhao's mother: She was, because she knew. Her dad had lung cancer and it took him only 6 months to succumb. Our old house had an attic and stairs. I would tell her to go upstairs to sleep and she would do it. I would be with her dad, and as soon as she heard me crying, she would wake up, run downstairs, sit in the recliner, and hold her dad's hand.

Her dad's condition kept deteriorating, and the two girls cried and said, "Dad, you can't die. What are we going to do if you die? Dad, you can't leave us."

Her dad was very worried about how I was going to bring up the two girls once he passed away, especially Zengzeng who was like life to him. He didn't pass away with peace of mind, because he had been the one supporting the family for the 10 years I had been living in Shanghai. He really couldn't close his eyes.

I said, “Don't worry - as long as I am alive, I will bring up our two girls. I won't abandon them. Even if I have to beg for food, I will support them till they can be independent." That's when her dad eventually closed his eyes and left. Looking back now, I don't know how I have managed.

I almost broke down, from the mental and family pressure, in the days following her dad's death. I had a fever of $41^{\circ} \mathrm{C}$ and was just lying in bed, unable to even open my eyes. The younger one was at school, and Zengzeng just stayed at my bedside, refusing to leave. She would be touching my head every now and then and asking, "Are you feeling better, Mom?" "Are you okay, Mom?" "Mom, you can't die. What will I do if you die?" It was so sad. Even now I feel sad about it.

We were living in the old house, so she would run downstairs and bring me a cup of warm water, saying, "Drink the water, Mom, and you will get better." She wouldn't leave my side. She just snuggled up to me with her head against my face. 
When I reminisce with my younger one now, I will tell her I spoil Zengzeng because she has it in her to be so caring and considerate, and that's the biggest reward for everything I have done for her. Zengzeng might misbehave sometimes, but when some of the kids without disabilities can't even listen well all the time, what more could I have expected of her?

After her dad passed away, I had to work to support the girls. Because of Zengzeng, I had to find a job close to home. There were a lot of people living in the same building and helping each other, unlike today's neighbors who hardly interact. When she was young, Zengzeng didn't understand a lot of things. She was also naughty and couldn't speak clearly. In the old building we lived in, she would be holding a bucket of water and dripping water downstairs, and the downstairs neighbor would yell at her and hit her. The two girls suffered quite a bit when they were young. Zengzeng once picked a flower from a neighbor's pot. The truth is that the social environment is different now. Back then, because of the flower, the neighbor yelled at Zengzeng and used a toothpick to poke her hand till blood showed.

That's why I said at last week's parents' meeting that the Special Olympics movement is good for directing society's attention to kids like Zengzeng to improve the treatment they receive. We have first-hand experience with how difficult it is to have kids like Zengzeng. I am very happy that things are getting done (including writing the oral history).

After my husband passed away, the Community Affairs Committee arranged for me to supervise bicycle parking which was very close to home. Zengzeng would run between home and where I worked. I was devastated seeing the bloody toothpick marks on her hand, so I said to the neighbor once I got home, "We all have kidsZengzeng has a disability, but your kids are not perfect either. Even though her dad passed away, her mom is still here. You have no right to treat her like that."

Other neighbors showed support for me. Zengzeng was, after all, a child with intellectual disability. Whereas other kids might listen to reason, she wouldn't because she believed what she did was fun.

I said, "How much is that one flower worth? I will pay you. You just can't treat my child like this." That lady then apologized. She was a nice person and felt bad about what she did. So I left it at that instead of making a bigger deal out of it. After all, Zengzeng did something wrong and we all lived under the same roof.

Before I started working, I was watching Zengzeng the whole time and taking her everywhere with me, so people never got a chance to hit her, because I would hold her hand even when we went grocery shopping.

When her dad was still around, the neighbors were nice. Then he passed away and I had to work. Zengzeng was naughty, and kids like her are hyperactive and get into trouble for no reason, but you can't follow them around all the time. So I told the neighbors that whatever Zengzeng broke, I would compensate them for it, but they shouldn't yell at her or hit her, because she is my child and it would hurt me if anyone yelled at her or hit her.

Q: Were there any kids bullying Zengzeng?

Zhao's mother: She didn't play with other kids. It's a habit from when she was young, because her sister would babysit her. Once the younger one got back from 
school, she would play with Zengzeng at home or take her out to play. Once the younger one got to a certain age and I had to work, she was the one protecting Zengzeng. She also cooked for Zengzeng. Zengzeng can do things too. She started helping me around the house when she was 17 or 18. By the time I got back from work, she already had the rice cooking. I didn't really want her to cook because of safety issues.

Q: Do you visit her dad's grave every year? To tell Dad Zengzeng's progress?

Zhao's mother: We do. We would tell Dad, "You were so worried about Zengzeng. But she has matured and become part of society, so you can rest easy now.” Zengzeng would say, "Dad, I am here to visit you. Do you know, Dad, your daughter has become a celebrity?" She can really tell a story.

It's very far to visit her dad's tomb. We have to take the subway, then switch to a bus. Sometimes we would ask a friend for a ride. Both girls suffer car sickness. Her dad should have peace of mind now, because the one person he had been most worried about was Zengzeng.

Q: How did you meet her dad?

Zhao's mother: If I could start my life afresh, I probably wouldn't have moved to Shanghai for marriage. Her dad's relative was my co-worker at the harvest station in my hometown. He collected the farmers' harvest and I issued receipts, and we worked as a team.

Her dad visited my hometown and came to the harvest station where his relative and I were busy collecting harvest. He asked his relative later whether I was single or had a boyfriend. His relative said, "No, this girl won't just marry anyone." I was pretty when I was young.

So his relative told me that someone was interested in me. I didn't take it seriously and asked him exactly who. He said, "He is my relative. He came to visit me and likes you. He is from Shanghai."

"From Shanghai? I don't know," I said. "I heard that Shanghai is a very nice big city. I have never been there."

Then a matchmaker came to talk to my parents. I was 22 then, and outside Shanghai, that's an age to get married, otherwise you would be labeled an old spinster and no one would marry you. My parents told the matchmaker to find someone for me. I was picky and already rejected a lot of people, so the matchmaker might have better luck with me.

It was my dad who really liked my husband. Since they were happy with him, my parents gave me a lot of pressure and I didn't have a choice. Then he took me to Shanghai to see where he lived. It was a very small room in one of those old-style stone buildings where the shared kitchen was downstairs and coal stoves were used for cooking. I didn't know how to take that.

My husband had a good education and wrote well. He wrote and sent to my house a thick stack of letters (gesturing to show thickness of more than one inch), like a book, telling us all about his birth, experience, and family background. I was at work and my mom received the letters, which my older sister opened and read to my parents. When I got back from work, my parents said to me, "He is such a nice guy. If he is not good enough for you, who is? Look here, he sent a book to you." 
My parents really liked him, but I was still resistant. My parents said, "If you reject him, you are no longer our daughter." You know daughters always end up obeying their parents. Once my parents said that, I had to agree, "Okay fine. I will marry him. That's what life is. I don't want to pick anymore, I will make do and have a family." So I married him.

Q: How old was Zengzeng's father at that time?

Zhao's mother: He was more than 10 years older than me.

Q: Not too bad.

Zhao's mother: It was considered a big gap in age back then. My mom said, "You don't have a good personality and are very stubborn, so you should marry someone much older who can put up with you and spoil you." My husband really spoiled me. After I moved to Shanghai, I didn't work for 10 years. My husband supported me. He said that if a man can't afford for his wife to stay home, he should just not marry at all. He was a typical man's man.

Q: What did he do?

Zhao's mother: He had a stable job, which he quit later to start his own business. In the 1980s, it was easy to make money in stocks in Shanghai. He and his friends also contracted for several buildings across from Changhai Hospital, but he got sick before the construction was completed. He had to give up his share of the contractor business and couldn't get any of his own money back. It was a very difficult time. Once a person passes away, however much money people owe him, there's no way to get it back. I did try to get some money back but people treated me to long faces and even threatened me with physical violence. I eventually gave up. I couldn't get any money back, especially as I was not originally from Shanghai. I still have the IOUs. Before my husband passed away, he made calls saying, "Please pay the money back to my wife, she needs it to support herself and the two girls." Once he passed away, no one paid a single penny back.

Q: So you had a happy family and were in a good financial situation, but your husband got lung cancer...

Zhao's mother: Right. My daughter often says that if her dad hadn't passed away, our financial situation wouldn't have been so bad. My husband was super smart. He would at least have guaranteed that the two girls wouldn't suffer. His death was unfair to the two kids, of all people. He totally spoiled them and doted on them...

\section{Grateful to School for Zengzeng's Present}

Q: Had you ever thought about sending Zengzeng to preschool or elementary school? Zhao's mother: I kept her with me and didn't send her to either preschool or elementary school. I did think about that, but decided against it, because she couldn't control herself and threw tantrums all the time. She might hurt other kids at preschool by bumping into them or hitting them, so I figured it was better to keep her with me. Back then, there were no preschools specifically for Down babies. 
Our old house was close to Datong Road. I became aware of an intellectual development school there especially for kids like Zengzeng, so I sent her to that school. After 2 years at the school, we were relocated by the government to where we live now. And 2 years after that, the intellectual development school relocated to our neighborhood. So we were really lucky.

I had a hard time with school drop off and pickup. I worked at Wujiaochang. Before going to work, I would carry her on my bike to school. I took my lunch break at $2 \mathrm{pm}$, which was when I would bike to the school and pick up Zengzeng, then I would go back to work. The truth is that if you have kids like Zengzeng, as long as you can commit on your part, the kids can have a normal life, but you really have to commit. Without that intellectual development school, Zengzeng wouldn't be where she is today. Right now, she can at least understand the news. She really likes watching the news. And she can write her own name as well as simple characters.

$\mathrm{Q}$ : When she was new to the school, did she have difficulty fitting in or was she reluctant to go?

Zhao's mother: Not really. Because I had to work and her sister had to go to school, she was lonely at home by herself. There were a lot of kids at school and it was more fun there. Ms. Gong at the school was particularly nice and caring towards her, because she knew our family situation. Sometimes when I was delayed at work and late to pick up Zengzeng, she would keep Zengzeng with her and watch her for me, and always called me whenever there was any issue.

Q: What did she learn at school?

Zhao's mother: The books she used were simpler than those for kids without disabilities. She learned math, Chinese, and drawing. Zengzeng is very good at watercolors, and one of her landscape drawings won an award when the school sent the students' works to a city-level competition. Then a teacher on Linfeng Road told me, "She loves drawing, bring her to my place and I will teach her." I was too busy with work and didn't have time, that's why Zengzeng had to stop going to the teacher's free drawing lessons.

She also learned dancing at school. She danced very well in the number Grateful Heart and performed at a show in Zabei District. Now at home, sometimes if you put on some music, she will dance her disco dance. She also likes to watch musicals and to sing along.

There were also craft classes where she learned to make small things like bunnies. On top of that there were PE classes. She ran in the class. The running that took her to Special Olympics World Games got its start at school.

$\mathrm{Q}$ : Teachers at that school are all professional special education teachers and very experienced.

Zhao's mother: Just being professional isn't enough. They need to have patience, which some of them don't. Even parents don't have patience, let alone the teachers. So that's understandable and we have to be considerate towards the teachers. Zengzeng was hyperactive at school, and I was worried that she would get into trouble by hitting other students. So whatever happened to her at school, like when she fell, I never really minded. I would just take her to the doctor myself, because I am the parent and I knew that she was a hyperactive child. If I demanded an explanation from the 
teacher for every time she fell, that would be extra work for the teacher. Parents should be considerate towards other people and other people will be considerate in return. It's all mutual, being tolerant and considerate. Sometimes the teacher would call and tell me when Zengzeng was injured, and I would say, "No problem, no problem, just a minor one I'm sure. Don't worry about it, I will take her to see a doctor when I have time." When it comes to your own kid, you don't complain. You just take responsibility.

I often tell Zengzeng, "Zengzeng, you are the smartest. Your sister is not as smart as you are and she should learn from you." It makes her very happy and makes her believe that she is smart. She has self-respect, and she understands, not like some other kids who are totally clueless. If you refer to her as slow, it hurts her. Someone joked with her saying that Zengzeng was slow, and she retorted, "You are slow. You are not as smart as I am." She can carry on conversations, so we must encourage kids like her.

The restaurant manager would call me sometimes and I would tell him to sweet talk Zengzeng into doing things he wanted her to do. This trick works as well at home. I would say, "Zengzeng, Mommy doesn't want to move. Can you please pour me a glass of water?" She would say, "You can do it yourself." And I would say, "Zengzeng, you are the sweetest and smartest. You are Mommy's sweetheart, not your sister." That's how I get her to fetch me water. She needs praise and encouragement and is over the moon when you praise and encourage her.

Q: You've got it all figured out. So you said that Zengzeng was pretty happy at school. Did she make friends with any classmates?

Zhao's mother: Making friends! Even now, her old classmates will call her up and ask what she is doing. She'll tell them she is working and they'll visit her at the restaurant.

Q: Did you drop her off and pick her up from school?

Zhao's mother: At first, I dropped her off and picked her up, but then I figured I should let go and have her walk to school and back home, which is how she goes to work now.

One time she was walking home from school and took the wrong turn. I went to school to pick her up and couldn't see her. I felt like I was losing my mind and started sweating all over. She knew which direction we lived and knew that she was lost, so she went to a bus station and just stayed there. A lot of passersby surrounded her and it was clear to them that she had some disability. Someone asked her, "Where do you live? I can take you home and feed you something, then we will send you home." No matter who approached her, her answer was "No".

It got dark and was already seven or eight. I still couldn't see her as I rode around on my electric bike, and I was desperate and ready to call the police. I stopped by the neighborhood police station and no one had seen her.

Several adults sat next to her to keep her company, because she refused to go anywhere or to eat anything offered to her. She didn't cry and wouldn't talk. She just sat there. People asked her where she lived and offered to send her home, and someone asked to see her school bag to look for an address or phone number. She refused to show anyone her schoolbag. 
Eventually there was no choice but to call the police and a police car took her to the station. She recognized the place and showed her schoolbag to the officers. They saw the name of the intellectual development school and called the school. The school called me and reached my younger one who had stayed by the phone. So I went to pick up Zengzeng at the police station. I asked how she was feeling, and she said she got to sit in a police car with A/C and felt really comfy. (Laughing).

Q: You did an excellent job teaching her about safety.

Zhao's mother: I had to, I had to. I told her a long time ago, "If you ever get lost, you can never ever go with a stranger. If someone abducts you and sells you, you will never see Mommy again and no one will be able to help you. If you find yourself lost, just stay there and don't wander off. If you see the police, tell them that you are lost." I had been teaching her about this since she was young, because after her dad passed away, I was the only one bringing up the girls and I worried about them getting lost. So I told her and she said she understood.

I taught her to ignore strangers talking to her, to go straight to school without stopping to talk to anyone and to ignore even people from our apartment complex if she didn't know them. People in our apartment complex tell me that I have done a great job educating Zengzeng. Kids depend on education from their parents. Zengzeng knows to give her seat to the elderly on the bus. When I send her to the bus station, people all know me and tell me, "You have such a good kid. She always gives her seat to the elderly. She has such good manners, even better than persons without disabilities."

\section{Special Olympics Star Groomed in Communication}

Q: It was reported that in 2004, Zengzeng participated in Special Olympics leadership training. How did she get picked for the training?

Zhao's mother: The truth is that wherever Zengzeng goes, people like her. The teacher at school liked her too and said she was cute. She took Zengzeng to Sichuan for the Special Olympics leadership training and something funny happened on the trip. Ms. Shen rode the train with her. She slept in the lower bunk and Zengzeng took the upper one. I had packed some snacks for her. Ms. Shen said, "It's late, don't eat anymore-you should sleep now." Zengzeng threw a tantrum and just dumped her unfinished food onto the lower bunk. Ms. Shen later said that she couldn't exactly get mad at her. I said, "Yeah, she is too naughty." And Ms. Shen said, "At the parties on some evenings, Zengzeng would sulk. So she just sat down, took off her shoe and threw it onto the stage with a loud 'bang'." Kids like Zengzeng are hyperactive. The teacher said she couldn't exactly get mad at her because when she behaved, she was a model kid.

Q: Was that the first time Zengzeng travelled by train? Did she like it?

Zhao's mother: It wasn't the first time. My hometown is Hefei in Anhui, so I often took them to Hefei by train. But that was the first time Zengzeng was away from me, and she stayed in Sichuan for 3 days if I remember correctly. As long as she goes 
with people she knows well, she is okay. Ms. Shen was her PE teacher and taught her to run.

Q: Zengzeng was picked for Special Olympics training not just because she was cute, but because she was good at PE, right?

Zhao's mother: Right. She had been running for a long time. Back then, she was walking to school and back home every day. It took at least 40 min to walk from my house to the school on Baode Road. At first, I would walk with her, then she started walking by herself. She would walk and play on the road, taking in everything on the way, which was fun for her. So it would take her more an hour to get to school.

There's a bus from my house to the school but I made sure she walked instead of taking the bus. Because she got out of school early, she would have nothing to do at home. Walking was good for her and for exercising her legs.

At school, the teacher was always asking her to run. She started by running $100 \mathrm{~m}$ and was really good at it. Then she gained weight which slowed her down. By the time she was filmed in the commercial, she had already put on some weight.

Zengzeng started competitive running after she came back from the Special Olympics leadership training. It was back then that various kinds of Special Olympics sports meets started. Zhabei District organized some, so did every other district, and Zengzeng went to them all. The teachers would take them and parents would tag along. I signed on to volunteer and followed her everywhere.

Zengzeng loves sports, so she wanted to compete in all of the events as long as there was no cap. There was a shot put event and she told me it sounded fun, so I encouraged her to participate even though she couldn't even close her hands around the shot. I told her to be careful and not to throw it onto anyone's foot. Since she had to hold the shot with both hands, she couldn't really throw it far and it was hilarious to watch. I asked her if she wanted to compete in this again and she said, "No, Mom, it's too heavy, I won't participate in this again." It was fun taking her to the meets. She even tried competing in badminton and it wasn't really for her, (laughing). There were other events that I can't recall now.

So she tried many events and never went back to them. Running is the only event she trained and competed in consistently. She would train 30-60 min after school sometimes. Then the school found a place in Zhabei Sports Stadium where she would train on Saturdays and Sundays.

Q: In 2006, the TV station went scouting at the school and picked Zengzeng for the Special Olympics promotional film.

Zhao's mother: Right. Zengzeng was still attending that school. It was 2006 and China was going to host the Special Olympics World Games. The director visited the school to scout for a promotional film and picked Zengzeng on the spot. I was at work during the day. As soon as I stepped into the house that night after work, Zengzeng told me, "Mom, Mom, the director is coming to our house to shoot a commercial tomorrow." I said, "What commercial? Are you daydreaming again?" Zengzeng insisted that it was true and she wasn't kidding me, and I was still doubtful until Ms. Shen from the school called me that night to tell me the same thing. Then I believed it. 
So the director showed up the next day to film our family and our apartment complex. The TV commercial was to deliver the Special Olympics message of "If you can, I can, too" and to tell the story of "Zengzeng My Child".

Q: Was that your first time participating in a publicity campaign?

Zhao's mother: Yes, the first time. We have been doing that a lot ever since. So the promotional commercial had to be shot before the Special Olympics World Games and the filming took place at a sports field in Zhabei. We arrived in the morning and Zengzeng's shooting started in the afternoon. I was given a lipstick and told to use it before kissing Zengzeng on the face. So I did that and the picture came out really nice.

Q: Pictures of Zengzeng were everywhere back then, and Mom's love and society's love were loud and clear in the lipstick marks you had left on her face.

Zhao's mother: Right, the picture was made into posters on light boxes and public buses. It was such a nice picture.

She had to run many laps during the filming. It was extremely hot, and I found the heat unbearable even though I was just watching her from the sideline. I asked her if it was too much for her and she said she was okay. You know how long it takes to film a commercial? She had to run one lap after another and I joked that she must have lost weight that day. There were two female crew members who took very good care of her, wiping her sweat and keeping her cool. The commercial was filmed at a lot of locations including the ferry boat near the Bund.

Q: Once the promotional film was released and the posters were put up, Zengzeng became a celebrity in Shanghai. How did that impact your lives?

Zhao's mother: The impact on our lives...A lot of people cared about us, and Zengzeng got really busy. She went to the USA with the Special Olympics committee, TV crew, and special police forces to receive the torch. People from Shanghai TV liked to joke with her, saying that Zengzeng liked good-looking guys and could really talk and was quite somebody. That's the way she is at the restaurant too. I took her to an activity the other day and she was talking the whole time. So I packed a suitcase for her for the US trip, and she came back and told me, "Mom, the airplane turned round and round and I got so sick that I threw up. And I didn't like the food there, so I ate instant noodles." She wasn't used to the food in the US. Other than that, she had a great time attending the activities there. She was part of the delegation receiving the torch and meeting with the US President.

I was with her for all of the activities held in Shanghai. Mrs. Shriver, ${ }^{3}$ who has since passed away, came to Shanghai for a ceremony and was opening a bottle of champagne. Zengzeng stood next to her and looked so short. The champagne gushed out with a loud "pop", and Zengzeng looked at me sitting there in the audience. When she came back, she asked me if I had enjoyed the show. She was so very happy.

\footnotetext{
${ }^{31}$ Mrs. Shriver (1921-2009): Eunice Kennedy Shriver, founder of the Special Olympics World Games, younger sister of former US President John Kennedy, and recipient of the 1984 Presidential Medal of Freedom for her contribution to the campaign for equal rights for people with intellectual disabilities.
} 
At the Special Olympics World Games, Zengzeng competed in running. It was at a sports field in Pudong and I went with her since I was a volunteer. She came in last, (laughing). It was in the afternoon and so hot. There were six athletes in her heat and she came in last. I asked her if she couldn't keep up with the others. She had a lot of engagements then, almost on a daily basis, which had cut into her training time. The engagements started in a random pattern in 2004 and became much more frequent following the commercial filming in 2006. The commercial was aired for a whole year from June 2006 to June 2007, before she went to the USA for the torch. Zengzeng had such a great time.

You can still find the closing ceremony of the Special Olympics World Games online, where the then-Mayor of Shanghai Han Zheng and Zengzeng handed the flag to the next host city. Sometimes I wonder whether it will be taken offline after a while, but my younger one said it will be on the Internet forever and will never be deleted. Every time I type in the key word, it pops up!

(Showing all kinds of Special Olympics photos and volunteer's certificates).

Q: We will bring a camera next time to take pictures of your pictures.

Zhao's mother: I think you can find all of these pictures online. Just search for them, they should be there permanently. There's also this picture of the Greenberg Outstanding Achievement Award. ${ }^{4}$

After the Special Olympics World Games in 2007, there were the Olympic Games and Paralympic Games in quick succession. Zengzeng was picked as the Olympic torchbearer and took over the torch on the Bund in Shanghai. We still have a replica of the Olympic torch at home.

I can't recall all of the Olympic activities she had participated in, since it has been a while. There were a lot. Sometimes I was exhausted, taking her to one activity right after another.

Q: Did Zengzeng find it exhausting?

Zhao's mother: No. She never complained of anything being too much or too tough. She loved going to the activities. During the Special Olympics World Games, I would take her to four or five activities on one single day, and I worried that she would be tired. But she said she wasn't. I found it hard to keep up myself.

Q: She must be in good physical condition because of the running.

Zhao's mother: I take her to annual physicals and everything is good with her. Because she's overweight, I was worried that she might have a fatty liver. This year's physical showed that she has a slightly fatty liver which is no big deal at all. All of the doctors know her and when they see her, they would tell her that her tummy is getting bigger and she needs to lose weight. And Zengzeng would reply, "What am I going to do when I can't lose the weight?" She knows how to joke around with the doctors.

\footnotetext{
${ }^{42}$ Greenberg Outstanding Achievement Award: In 2007, the Special Olympics Families' Forum for the Special Olympics World Summer Games held in Shanghai set up the Greenberg Outstanding Achievement Award to recognize outstanding Special Olympics family representatives, and Ms. Yi Zeng, Zengzeng Zhao's mother, was one of the recipients of the award. The award was named after Mr. Greenberg, Chairman of the Board and CEO of Starr Investment Group in the US who was that year's most generous individual donor to the Special Olympics World Games.
} 
Q: You just mentioned that you saw very apparent changes in Zengzeng after the Special Olympics World Games. What were those changes?

Zhao's mother: She can really communicate with other people now. Before, she would get mad at school from time to time. She has changed a lot and doesn't even throw that many tantrums at home. She feels that since she is the image ambassador, which she is super proud of, she will have to control her temper which is what celebrities do. When she walks on the street, people would know her by name and ask her if she is indeed the celebrity and the image ambassador they think she is. She would say, "Yes, it's me." People often recognize her on the street. When she takes the bus now, several of the drivers are super nice to her and always tell her to watch her step. Kids like Zengzeng have very straightforward thinking. Whenever people ask her, she would proudly tell them who she is.

Q: She has a very open and outgoing personality.

Zhao's mother: Yes, and she has grown even more outgoing because of her participation in those events including the 2007 Special Olympics World Games, and the Olympic Games and Paralympic Games in 2008. Following the Olympic Games, Zengzeng attended activities hosted by the community and the Disabled Persons' Federation, like meet-and-greets, presentations, and Communist Partybuilding seminars, and we were asked to bring and show her certificates, pictures, and souvenirs.

Then she tried Sunshine Home and didn't fit in because she didn't want to be with those kids. I asked her why and she said it's no fun. Kids like Zengzeng have the same mentality as persons without disabilities, in that they can never forget about their 15 min of glory. I told her to stay put at Sunshine Home while we started job hunting for her. Several weeks later, Papa John's was hiring, so she joined them.

\section{Making Money to Support Mom}

Q: According to media interviews, Zengzeng learnt to cook using flour when she was at the school.

Zhao's mother: Right. She stayed at the school for a total of 8 years. Curricula of elementary school and middle school were covered during the first 6 years, and for the last 2 years, she moved on to classes teaching hands-on skills. So she chose for herself a class where she learnt to make steam buns, noodles, and dumplings. When a reporter interviewed her later, she was kneading dough, with hat, apron, and the whole nine yards. The reporter said she looked like a chef, (laughing). I asked her whether the steam buns she made were delicious, so she brought some back for me to taste. At first, the buns were too hard and chewy, but they got better with the teacher's help. I asked her to make steam buns twice at home. She is very good at making noodles and not getting them all stuck together. She is also good at making dumplings. But steam buns are still a challenge.

Q: Does she still make any at home? 
Zhao's mother: Not now. Can't rely on her for that. She has to work and is already tired by the time she gets home. People would ask her how she plans to use the money she makes at work, and she would reply, "I am going to use the money to support my mom, because she has had a hard life." She really has changed a lot. When she was interviewed, she kept saying that once she started working, she would use the money to support her mom.

Q: When did she first have this idea of supporting you?

Zhao's mother: After her dad passed away, she saw how hard I had to work, so she started saying, when she was about 15 or 16, "Mom, when I grow up, I will find a job and make money and support you. Then you won't have to work so hard anymore."

Q: How did Zengzeng know that Papa John's was hiring?

Zhao's mother: The hiring information was on the Internet, but it was the Disabled Persons' Federation that told me about it. So I took her to the interview. I didn't really think she would make it, so both of us took it really easy. She later told me that she was asked to carry plates during the interview. Papa John's is a nice company. After several days, they notified Zengzeng to attend training. I took her to training every day. Since she started training late, she had to go to a designated place in Yangpu District, and the training lasted about 2 weeks.

Every day she came home, she would tell me what she had learned at the training, like making pizza, kneading dough, carrying plates, and greeting customers. I asked her to show me, so she opened the door and said, "Welcome. Would you like to take the table over here?" She carried a notebook with her every day and practiced at home.

Then the restaurant notified her to report for work, so I went with her and she signed the contract herself.

She started by greeting customers. A lot of people recognized her and asked, “Aren't you image ambassador Zengzeng Zhao?" She wasn't exactly low-key about it and replied proudly, "That's me." But it got tiring when she had to stand for a long time, so she was moved to the non-dining area to wrap knives and forks in napkins. She didn't really care where she was moved to because she was equally happy at all the workstations.

Q: Does she tell you about what happens at work?

Zhao's mother: She does, every day, like whether business has been good on that day. I would ask her if she has been behaving at work, and she would say, "I was very good at work and the managers all praised me for it." So we talk like that every night.

Q: Does she get to interact with customers?

Zhao's mother: When she first joined Papa John's, her job was to stand at the door to greet customers, so she had been interacting with customers a lot. Then the company moved her to the non-dining area to wrap knives and forks, and she is very happy at that job. A reporter interviewed her last time and asked her if she was happy at work. She replied, "I am happy. My mom works hard, now I want to make money to support my mom." She is such a sweetheart.

If I don't feel well and stay home on a certain day, she would say in the morning, "Mom, Mom, remember to take your medication. I have to go to work now. Wait 
for me to come home." And when she came home again, she would ask, "Mom, are you feeling a little better? Are you feeling a lot better? Are you feeling okay?" She really wants to know how I am feeling.

Q: Has she ever felt work is tiring and thought about quitting?

Zhao's mother: No, Zengzeng has never had those kinds of negative thoughts about work. My younger one gets tired at work sometimes and wishes for time off, but not Zengzeng. I joked with her, "Why don't you quit your job and stay home to eat, shop, and play?" She replied, "No, I can't do that. How can I make money if I don't work?" (Imitating Zengzeng's loud voice.) "There are a lot of people at work and no one except for me at home. What's the fun of eating, shopping, and playing?" Her co-workers are all super nice to her.

The worst Zengzeng ever does is to misbehave. The manager called me last time, "Zengzeng isn't listening well. She uses two extra napkins for wrapping the knives and forks." So I called her, "How are you doing at work? Are you behaving? If not, you should just quit and come home." "Oh no," she said crying, "I want to work, Mom." Then I asked her if she knew what she had done wrong and what to do about it. She said she knew and would apologize to the manager. And I said, "Okay, that's good then."

I had a talk with her when she came back, "When the manager talks to you, you need to respond, you know? You can't have any attitude. The manager is supposed to manage you and you need to respect the manager. Do you understand?" She said she understood. Kids like her don't always get it, after all, so you will have to constantly remind them.

When the manager assigns her work, she gets lazy sometimes and will sit there and play instead. All of the managers at the restaurant are really nice. I am the parent, so I know that kids like Zengzeng are not easy to manage. They have their distinctive personalities and get mad and moody sometimes. As the parent, I am very tolerant. Whatever happens to Zengzeng at work, I blame it on her. I told her to keep the transportation card hanging around her neck so as not to lose it. She had to take it off and of course she lost it. I have had to replace the card quite a few times for her commute. She would cry at the restaurant over the lost card, and the manager would call me about it. I told Zengzeng, "You can't cry at your workplace-you are already in your twenties." The manager didn't know what to do, so he offered to let Zengzeng use his own card. I said, "No, no, I will buy a new one for her. Lost is lost, it's okay." The manager knows how to get along with the other co-workers, but it's not as easy to handle kids like Zengzeng. So parents should be more understanding towards managers and co-workers at the workplace. Parents can be more tolerant because they know their own kids better.

Q: The manager told me that she works hard and takes her job seriously.

Zhao's mother: Yeah, the manager often praises her. Whenever he does that, Zengzeng will come back and tell me, "The manager said Zengzeng worked very hard today." She is still a child, isn't she? One time I went to the restaurant and a co-worker told me, "Zengzeng is being very good. Look at how clean she has wiped this table." Sometimes I would call the restaurant and ask how she is doing and I would be told that she listens well, really behaves, and does a good job at work. 
She works $8 \mathrm{~h}$ a day, from 10:30 to 7:30 pm, with $1 \mathrm{~h}$ for lunch. She has never complained that work is tiring. Whenever I ask how she feels about her work, she will say that she is happy. She has been working for 7 years now, so she is a senior employee in a way of speaking.

I asked if she wanted me to talk to the restaurant about transferring her to another one closer to where we live, and she said, "No, I want to stay where I am because the managers and co-workers are very nice here." To go to work by herself, she needs to take bus No. 845 and switch to bus No. 850, which takes less than 1 h. So she leaves the house at 9 am and gets home a little after $8 \mathrm{pm}$. Most of the time she commutes on her own. If I have free time now and then, I will go and pick her up from work.

When she first started working, she got lost once. I had asked her to wait for me to pick her up, but she left right after work. She missed her stop on bus No. 850 and got to the bus terminal. It was a cold winter in Shanghai and it was snowing. So she stood on the street, knowing that she'd missed her stop, that she lives somewhere in that direction, and that she just couldn't find her way home. But let me tell you how smart she is. She waved down a motorized cart which was operated by a very nice owner. She said to him, "Uncle, please send me home, and I promise that my mom will pay you." I didn't give her pocket money at that time because I didn't want her to run around wild once she had money.

I went around her restaurant many times looking for her, until past $1 \mathrm{am}$. Even though it was freezing, I broke out in a sweat. On the way home, I figured if I still couldn't find her, I would call the TV station to help. As soon as I got home, she came back in the motorized cart, rang the bell and asked me to go downstairs to pay the driver. At that moment I didn't know whether to be relieved or to be mad. So I went downstairs, and paid and thanked the driver profusely.

I asked Zengzeng, "How did you get lost? You know Mommy almost passed out from panicking.” She said, “Don't panic, Mom. I got back, didn't I? Don't be worried or scared."

Now she has my cell phone number, which she can recite sometimes. If she gets lost, she will either get a taxi or look for the police since there are many traffic cops around or go to where she sees 110 . She reassures me that she knows what to do. She is smarter now and knows directions better. She commutes on her own, although I pick her up if I get worried sometimes.

Q: Does she interact a lot with her co-workers?

Zhao's mother: I would think so. I don't go to her workplace often, in fact I don't go if I don't have a good reason to go. It's not good to always check in on her at work, as if I was paranoid. And I should be considerate towards other people at work there. I should also be supportive towards the workplace and not bother anyone there for no reason.

Q: You just mentioned that you saw major progress in her following the Special Olympics World Games, because she feels that she is a celebrity and should be able to control her emotions better. You also saw some major progress in her since she started working. Can you be more specific about this second progress?

Zhao's mother: Now I can let go. She used to be wrapped in cotton wool by me, like a baby. If I had kept her home, she would have remained the same. 
If I go out with her sister and leave her alone at home, I will tell her, "Zengzeng, enjoy your day off. I have cooked something for you. You know how to feed yourself." And she does know how to feed herself. She will never open the door if a stranger rings the bell. She knows how to protect herself now. For kids like her, you can't really have too many expectations. I just want her to be able to protect herself.

One time I was going on a trip with her sister and asked her to go with us. She said, “No, Mom, I won't travel. I'll stay and watch the house to make sure no burglars come. I saw on TV that there are many burglars around, so I need to watch the house. Have a good time, Mom." She spoke exactly like someone without disabilities. Another time I asked if she wanted to go to Hainan with me, and she said, "Mom, you can't go. I watched the news, something happened to the airplane, just like that. So you can't go now."

Q: She speaks as if she was the master of the house.

Zhao's mother: Exactly. Before she goes to work, she will say, "Mom, stay put and watch the house, there are a lot of burglars out there." She will tell you to watch out for this and that. If she hadn't stepped outside this house and ventured into society, she would not have made such progress. A lot of kids without disabilities have no common sense nowadays. So the truth is that being out there with persons without disabilities has broadened her horizons. Because she works at a place where the majority of employees are persons without disabilities, it has made a difference to her. She has changed and improved, and has come to understand more about society.

I would leave some money there and ask her to buy food for herself. And she would know how to do it and to wait for change. If I had kept her at home, she probably would have responded by asking where she could buy food.

Now she comes home from work and says, as soon as the door opens, "I am back. Anyone to welcome me back? Anyone at home? Come out and say 'Hi'."

$\mathrm{Q}$ (pointing at the small dog at her feet): And this is the one to greet her first.

Zhao's mother (laughing): Right, this is the one that runs up to her first. I will immediately say, "Welcome back, welcome back!" while hugging and kissing her. She is still clingy towards me, since I have brought her up all by myself after her dad passed away prematurely. She has had no one but me. If I don't respond right away, she will ask, "What's going on? You are not happy to see me back?"

If I go out while she stays home on her day off, she will hang up the laundry I have done and make all the beds at home. She washes small things like socks. We have always encouraged in her the habit of washing her own clothes. It doesn't matter if she can't wash them clean, I will wash everything again for her. But she does need to wash them herself. I had no choice anyway. Since her dad passed away, I have been busy making a living, so I had to teach her to do things for herself.

We are in a good place now. Despite her disability, Zengzeng has come a long way, and being her parent, I am very satisfied. People in our apartment complex always say that Zengzeng may look slow, but she is not. She would greet everyone she knows in the apartment complex and is really smart in other ways. All of the neighbors compliment me on what a great job I have done bringing her up to the way she is today.

$\mathrm{Q}$ : When did your financial situation start to improve? 
Zhao's mother: When my younger one started working and Zengzeng started receiving a government subsidy for persons with severe disabilities who are unemployed. We used to receive a low-income subsidy which was a little over 100 yuan at the very beginning. It went up to over 200 yuan later which was still next to nothing. But Zengzeng got the Papa John's job soon after she started receiving the government subsidy, so the subsidy stopped. She doesn't make much more than the subsidy. I pack food for her every day she goes to work and have to make it decent. And she brings sodas too. There's also the transportation fee for commuting. She only makes enough to cover her own expenses like clothes and going out on her days off.

But it's okay. I really just wanted to get her out there to help develop her mind. She can't stay home. Now that she is out there, of course it costs money, but it's worth it because she is being gradually included into society. Parents get old and leave, so the least I want for her is to be able to communicate with other people and to make a living.

\section{Contented Life Together}

Zhao's mother: My younger one is a sweetheart. Ever since they were young, she had been babysitting her sister, taking her everywhere she went and doing everything with her. They have never had a fight and their emotional bond is very strong.

Q: So your younger one only played with her sister and not with any other kids? Did she ever want to play with other kids instead of her sister?

Zhao's mother: I had to explain everything to her, telling her, "I have no choice. If Daddy were still alive, you would have the freedom to play with whoever you wanted. Now that Daddy is gone, Mommy has to work to support all of us, so you will have to keep your sister company." It might not have been the ideal situation for her, since other kids played with whoever they wanted, right? Sometimes she would bring Zengzeng to play with her classmates. She is 1 year younger than Zengzeng and people used to mistake them for twins.

When I was at work, it was always my younger one babysitting Zengzeng. I would cook two meals in the morning which they would microwave when they got home. I worked at a restaurant and used to get off work at $9 \mathrm{pm}$. Then I switched to night shift starting at $9 \mathrm{pm}$ in order to take better care of the girls.

Since I would be at work, I always asked my younger one to drop off and pick up Zengzeng. When Zengzeng first started working, my younger one crossed railroad tracks on her electric bike and fell off the bike when she made a turn. She was bleeding all over the place. I cleaned and disinfected the wound and gave her antibiotics, but she has a scar on her tummy now. Zengzeng didn't know how to take the bus at the beginning, so we dropped her off and picked her up on our electric bikes. Then I took her with me to ride the bus, that's how she learned to do it herself.

Sometimes my younger one would joke with Zengzeng, "Zengzeng, you got paid. When are you going to take me out to eat? It's always me taking you out." Zengzeng would say, "Mom has the money—ask Mom for it," or "Money is in the bank, you 
go get the money at the bank." My younger one would say, "It's your money that's in the bank, I have no access to it." And Zengzeng would tell her to ask me for the money.

On our days off, we would all go out together. My younger one would say, “Zengzeng, I am buying today, are you coming? I will take you out to eat." Zengzeng would say, "Sure, I will pay you back when I get paid." And my younger one would say, "I have never seen a single penny from your pay." They like to joke with each other.

I gave birth to Zengzeng, but eventually her sister will have to take care of her. So my younger one has learnt from very early on to be very nice to Zengzeng. There are true stories of the younger sibling being mean to the older sibling, but it all depends on what kind of behaviors the parents encourage. I have always told my younger one, "Your sister is my child, so are you. You need to treat your sister as your equal." Kids cannot do without education from the family, just like Zengzeng would have been having a hard time out there without help from society.

Q: Did your younger one have good friends among her own classmates?

Zhao's mother: She did.

Q: Did they hang out?

Zhao's mother: She brought them home to hang out sometimes.

Q: The two girls went to different schools. Was your younger one's school far away?

Zhao's mother: Not really, 15 min' walking distance. Zengzeng's school was farther away. Now that she has grown up, my younger one would recall, "On rainy days, everyone was picked up by either Dad or Mom. I had no umbrella and had to walk home on my own. Mom, I feel bad for myself when I think about it."

Q: You couldn't possibly have picked up both of them.

Zhao's mother: I told her, "You are not the only one feeling bad. Mommy feels bad sometimes too. I feel like crying, but I can't cry in front of you because that will make everyone sad. So many years have passed, and it's too painful to always look back. So we should look forward, honey, and don't dwell on things."

I was only 33, with two kids, when their dad passed away. A lot of people nowadays are still single at that age. At the school my younger one was going to, when her dad was still alive, the teacher was super nice. Once he passed away and I had to work, the teacher would insult her by saying, "Your mom has taken off with someone and abandoned you." My younger one would say whenever she looks back, "Why was the teacher so mean? She often made a point of telling me that my mom had abandoned me and she always had a long face for me." If I couldn't get away from work for the parent-teacher meeting, the teacher would take it out on my daughter the next day. My younger one said, "I didn't know how to fight back because I was so young. Now I would probably talk back to the teacher."

After graduating from vocational school, my younger one studied for an associate degree while working fulltime, and the school was right next door. She is mentally tough, not the attention-seeking type like some other kids. She often says that since there is no man in our house, the two of us will have to be the men and to rely on 
ourselves. We have no relatives in Shanghai, so we have taken one step at a time and got to where we are today, all on our own.

Q: Were there fees for the vocational school and associate degree studies?

Zhao's mother: The government waived part of the fees because of the extreme financial hardship of our family.

Q: It must have been exhausting, working full time during the day and studying at night.

Zhao's mother: It was, but my younger one was determined.

Q: How does your family spend time together on your days off?

Zhao's mother: We all have weekends off, so Zengzeng will watch TV at home. She likes watching news, music, and TV series. She can memorize those cop shows from beginning to end. If I miss a couple of episodes, she can recount them to me. To tell you the truth, I forgot all about the reporters who had interviewed us. But if she sees some of them on TV, she can tell who is hosting what show and who is who. She remembers all and knows all.

If there's breaking news on TV, she would ask me to watch or brief me on it, like if someone was being totally ungrateful and killed his dad.

She will play board games or poker while watching TV. There are pens over there, so she writes sometimes or flips through books (there was a collection of novels on the table) and copies characters from the books. That calculator is hers too and she does addition on it sometimes. I would say to her, "Zengzeng, you are the government accountant. You have to do the books every day you come home and record my daily expenses."

(Looking for a notebook on the table).

Q: Does she punch random numbers into the calculator or numbers from the receipts of that day?

Zhao's mother: She just enters random numbers and writes down whatever shows up on the calculator. I would tell my younger one, "Look, Zengzeng is doing the books again. She is calculating our expenses from today and the expenses of your workplace as well." See, all of these were what she got on the calculator after she had entered her numbers.

$\mathrm{Q}$ (pointing at the notebook): This was probably a misspelling.

Zhao's mother: This notebook was especially bought for her. She was using her sister's notebook. Her sister wrote a lot of things in it at her workplace and diaries too, so she just turned the notebook over and wrote on it. Then we took her to the supermarket and asked her what kind of notebook she wanted. She wanted a big one and her sister said to just get her a big one. Look, she is running out of blank pages.

She keeps herself fully occupied at home on Saturdays and Sundays. I told her that she gets busier than when she is at work. She is trying to develop herself.

Q: I asked her the other day if the calculator on the table is for her to use. She said, "No, not for me. My sister uses it."

Zhao's mother: It's actually for her to use. Everything on this table including the board game and poker cards is for her to use. When she gets home at night, she will sit here with the TV on after her shower. 
Q: During lunch break at the restaurant, Zengzeng carried her white bag to an empty VIP room to write. Do you know what she writes?

Zhao's mother: I do. She takes a book to the restaurant that her sister has finished reading at home and copies characters from it. Sometimes she would take an English book and copy the English.

Q: Does Zengzeng like dogs? How long has the dog been with you?

Zhao's mother: We have had the dog for 7 or 8 years. Both girls love it. Nowadays, both grownups and kids love pets, right? At first my younger one bought a Bichon Frise, but it got sick after 1 month and couldn't be saved, even after we spent more than 1,000 yuan at the pet hospital. My younger one was howling over its death, and Zengzeng cried too. So I had to tell my younger one to get another dog. My friend's dog happened to be breeding, so we got a puppy. Zengzeng walks the dog on her days off, in the little garden in the apartment complex. When she goes to work, I walk the dog, twice a day.

Q: Does Zengzeng play with the dog when she gets home from work?

Zhao's mother: We call the dog Feifei. So when Zengzeng gets home, she will say, "Feifei, your older sister is back." And when she goes to work, she will say, "Feifei, be good, your older sister is off to work."

Q: Does Zengzeng feed the dog?

Zhao's mother: She does. She will check if the bowls have water or food and refill them if she needs to. I have told her not to overfeed the dog but she is worried that it will starve.

Q: A lot of families buy pets for kids now to keep them company as they grow up. Zhao's mother: Right, all of the kids like pets now.

Q: You have done a great job bringing up both your kids.

Zhao's mother: I wish I had done more for them and pampered them more, but I didn't have the financial ability or the time. When I talk to my younger one, I tell her, "I have given my all to bring you girls up, so don't get mad if there's anything I missed. Mommy wants a perfect happy family too, which would have been possible if your dad was still alive, right? But what can we do? This is the hand life has dealt us."

I am very satisfied now. Zengzeng has been to the Special Olympics World Games, and wherever she goes now, people like her and compliment me on having taught her good manners. When I went to the restaurant the other day, two co-workers told me that of all the young employees there, Zengzeng is the most talkative.

Zengzeng has really come a long way. She got lucky too, in that the Special Olympics World Games was held at the right time for her and was exactly what she needed to be inspired. She graduated from school after the games ended, and Papa John's hired her right away, so she got lucky there too. As parents, we have paid a heavy price. We have brought the kids into this world, and it's not their choice if they were born with disabilities. So parents need to find the courage to face it. If we can't do it and just keep the kids isolated at home, the kids will never have the courage to face the world.

Zengzeng has found the courage to face the world, but a lot of families haven't. Some of the parents simply don't want to lose face. I tell my younger one that 
Zengzeng is my own child, and whatever her condition, she has already ventured into society and can be involved in it, so I am very proud of that. It's true that I have a child with disability, but I have accepted that. Kids are ours to keep, and if the parents can't be brave about it, they can't blame others for discrimination. There are so many kids like Zengzeng in the world now and they all need love and care. Society is more caring towards persons with disabilities now, so why keep the kids at home and shut out the world for them? Life will be different once you embrace it. We have found the courage ourselves, so we should help others do the same. That's why I liked the idea of this oral history as soon as I was made aware of it, because people need to know more about us. Zengzeng is where she is today because of the government and society. Society is making progress, so are the kids.

\section{Interview with Zengzeng Zhao's Co-worker (I)}

Interviewee: Ms. Qu, works in the dining area

Interviewers and writers: Mei Liao and Zian Li

Interview date: July 15, 2016

Interview place: Restaurant where Zengzeng Zhao works.

Q: How would you describe Zengzeng's work?

Ms. Qu: She listens well. She arrives early every day. Once she gets here, she will refill the sauce, clean up, refill the sanitizer, wash the mops, and separate them. The red mops are for the dining area and the green ones are for the non-dining area. She never mixes them up because she is so used to separating them. She is also the only one cleaning up our break room. When we get busy sometimes, we would ask her to help and tell her specifically what to do, and she can get a lot done like wiping the fridge doors and tables.

After she finishes everything, she will take a break and chat with someone. During the 1-h lunch break, she will go to a VIP room and sit there to write or to draw.

Q: Is there anything different about working with employees being cared for?

Ms. Qu: The co-workers have more pressure because they will have to watch the employees being cared for and lend a hand sometimes. Not even persons without disabilities can always do a perfect job, so it's normal for employees being cared for to make some mistakes.

Q: How does Zengzeng get along with her co-workers?

Ms. Qu: She had a good upbringing and has good manners, and always greets everyone. When she is in a good mood, she will snuggle up to me and kiss me and tell me she likes me. When she is in a bad mood, she will tell me to leave her alone. She is like a child.

Since you are here to interview her today, I am sure she will tell everyone all about it afterwards, like she got an interview today and what was said during the interview.

Q: Does Zengzeng often throw tantrums?

Ms. Qu (laughing): You go ask her that. She will tell you herself. 
Kids like her, if you let her have her way, she will behave really well. We all have kids ourselves, so we understand and we do care about them.

The benefits are good in Shanghai. Where I come from, which is in Northeast China, kids like Zengzeng stay home and are supported by the families, since no one will hire them to work. Here the company takes care of them and pays into their social insurances so that they have something put aside for when they get old.

Translated by Cissy Zhao

Edited by Andy Boreham and Zijian Chen

\section{Interview with Zengzeng Zhao's Co-worker (II)}

Interviewee: Mr. Zhou, Manager on duty

Interviewers and writers: Mei Liao and Zian Li

Interview date: July 15, 2016

Interview place: Restaurant where Zengzeng Zhao works.

Q: How would you describe Zengzeng at work?

Mr. Zhou: I was the one who trained all of the employees being cared for. At first, Zengzeng was the most challenging one. There's a backdoor in this restaurant, and she would leave through that door and disappear whenever something upset her. So we had to immediately send someone to look for her. Luckily, she didn't walk fast and we could always find her within a $1.5-\mathrm{km}$ radius. She has improved since then and won't leave the restaurant for no reason.

She used to usher in customers, but a lot of customers found it hard to accept, so we moved her to the non-dining area. She will finish everything she is assigned for that day, and take a break to practice writing or to sleep. Zengzeng has pretty severe intellectual disability, so we prefer not to give her other jobs in the kitchen, since there are ovens in the kitchen.

Q: Are ovens dangerous for employees being cared for?

Mr. Zhou: Unlike in some other restaurants, we don't have open fryers and the ovens are well sealed so they're relatively safe. We have been repeatedly telling the employees being cared for from day one that the ovens are hot. The most dangerous thing we have around here are the knives for cutting vegetables and salad. Everyone is careful, so we haven't had any injuries so far.

Q: Does Zengzeng go home by herself after work?

Mr. Zhou: Sometimes her uncle picks her up.

Q: I saw you talking to Zengzeng in front of the break room just now. Did Zengzeng...lose her temper?

Mr. Zhou: She did.

Q: What happened?

Q: You interviewed several employees today and chatted with us. So Zengzeng was unhappy about it. She said she is the celebrity and should be the only one to be interviewed. So I tried to reason with her and as we were talking, she pointed her 
finger at me and said, "Let me warn you..." I had no choice but to scare her by saying that I would call her mom.

So I called her mom in front of her. I actually just told her mom that someone was interviewing Zengzeng today and asked whether she knew about it, since you have been here the whole day and we were obligated to let the parents know. Zengzeng believed that I had called to tell on her to her mom, so she was really scared and got unhappy. Then she left after work.

Q: They do show their emotions right away.

Mr. Zhou: Happy or unhappy, they don't hide it.

\section{Interview with Zengzeng Zhao's Co-worker (III)}

Interviewee: Ms. Zhou, Manager on duty

Interviewer and writer: Mei Liao

Interview date: March 16, 2018

Interview place: Restaurant where Zengzeng Zhao works.

Q: Do you still remember what it was like when Zengzeng Zhao joined the store?

Zhou: A lot of people from the Disabled Persons' Federation came with her and introduced her as the torchbearer for Special Olympics, which deeply impressed everyone. New hires at our store asked to have pictures taken with her because she was a celebrity and her pictures were put up everywhere at the subway stations 2 years ago.

Q: Did any customers ask to have pictures taken with her?

Zhou: Customers...She was greeting customers at the entrance for a long time, before all of the employees being cared for were moved to work in the non-dining area.

Q: What station does Zengzeng work at in the non-dining area?

Zhou: She mainly wraps plastic knives and forks.

Q: Does she work Monday through Friday?

Zhou: Right, and she gets weekends and holidays off. Her work hours are different from everyone else's. ${ }^{5}$

Q: During her interview, her mom said, "Leader means someone who leads you, so you must respect the leader." Does Zengzeng get a little moody sometimes?

Zhou: She does. When she is in a good mood, you can tell her, "Zengzeng, we are running low, so can you wrap some more knives and forks since you have tomorrow off?" and she will happily agree. But when she is in a bad mood, she will just say, "Leave me alone."

Her mom told her to listen to the leader, so it sounds like the manager on duty talked to her mom about her refusing to follow instructions and to do her job and throwing tantrums and things around. We have an older lady here who is from Northeast China.

\footnotetext{
${ }^{51}$ Zengzeng Zhao has severe disabilities, so the restaurant gives her special treatment in arranging work hours. The other employees work varying shifts and have no fixed days off.
} 
Whenever she feels that Zengzeng is being contrary, she will call her mom. Her mom will get mad at her when she gets home and she is scared of her mom getting mad, so she will apologize to the older lady when she comes to work the next morning. She even calls this older lady her "second Mom" and attaches herself to her as soon as she gets to the store. The older lady must have talked to her mom multiple times.

Q: Is the older lady in charge of Zengzeng?

Zhou: Not really. Zengzeng will misbehave at work and we will let it go, but the older lady won't and will want to talk to her parent.

Q: Oh, maybe the older lady feels like she has the responsibility of a mom. Zengzeng's mom said that one time Zengzeng used two more pieces of paper to wrap knives and forks.

Zhou: Our practice is to have one knife and one fork inside each bag, the knife and fork each wrapped in a piece of paper. We will give her two bags of paper every day and tell her, "Zengzeng, you will need to finish these two bags." She feels that she can get off work early if she finishes early, so she will wrap two or three knives and forks in seven or eight pieces of paper which makes the bags so bulky. When we are not busy, we will unwrap what she has done. But when we get busy, we can't unwrap everything.

Q: Does the parent communicate with you a lot?

Zhou: Her mom mostly communicates with the store manager. When I am the manager on duty, I seldom contact her. One time, Zengzeng used the restroom at the supermarket next to us. When she opened the door coming out, she knocked down a very young girl. The girl bumped her head on the step and bled, and her grandma brought her to the store. That was the only time I contacted Zengzeng's mom and asked her to take the girl to the hospital.

Q: You hadn't interacted with employees being cared for before joining the store, had you?

Zhou: No. When I learned that there would be employees being cared for joining the store, I worried about what to do since I had never interacted with any before. I figured that the worst that could happen was to quit. Then the store manager reassured me that I should be able to get along with the employees being cared for and I asked whether it was because I have a loving nature and he said it was because there's not much difference between me and them. So the employees being cared for came and what do you know, I have been getting along fine with them ever since. (Laughing).

Q: When you have new regular employees joining the store, do you need to train them or remind them of how to get along with employees being cared for?

Zhou: We will tell them upfront that our store is a Caring Restaurant. ${ }^{6}$ That's one thing we must tell them when they join the store.

Q: When you are with the employees being cared for, do you feel relaxed or under pressure most of the time?

\footnotetext{
${ }^{61}$ A Caring Restaurant (爱心餐厅) is a demo store for how Shanghai Papa John's is creating jobs for people with disabilities, and there is a large percentage of employees with disabilities at the store. Papa John's has two Caring Restaurants in Shanghai.
} 
Zhou: When we are not busy, it's fun to see them goof around. But when we get busy, they can drive me crazy.

Q: What do you mean by "drive me crazy"?

Zhou: The orders are not being made and they look like it's none of their business. You are panicking whereas they are taking it easy and taking a break in between so many orders.

(Co-workers came to consult Ms. Zhou about work, and customers started arriving at the store, which brought the interview to an end).

\section{Interview with Zengzeng Zhao}

Interviewee: Zengzeng Zhao

Interviewers and writers: Mei Liao and Zian Li

Interview date: July 15, 2016

Interview place: Restaurant where Zengzeng Zhao works.

Q: How did you get to work this morning?

Zhao: By bus.

Q: You rode the bus by yourself?

Zhao: Right.

$\mathrm{Q}$ : Did you say "Hi" to anyone on the way here?

Zhao: No, I don't talk to anyone I don't know.

Q: How long did it take for you to get here?

Zhao: About $10 \mathrm{~min}$.

Q: Just 10 min?

Zhao: Right.

Q: When did you leave the house?

Zhao: I...left at 9:15.

Q: When do you start work every day?

Zhao: I start at 10:30.

Q: 10:30?

Zhao: Right.

Q: So you arrived early today.

Zhao: I did, for work.

Q: Do you arrive early every day?

Zhao: I do.

Q: What did you do today at work?

Zhao: I refilled the ketchup and Thousand Islands salad dressing.

Q: Oh, you refilled them.

Zhao: Right.

Q: What did you do after that?

Zhao: After that...sanitizer.

Q: So you refilled the sanitizer. 
Zhao: Right.

Q: And after that?

Zhao: I washed mops.

Q: You washed mops.

Zhao: Right.

Q: What did you do after that?

Zhao: Dinnerware.

Q: Did you wash them or collect them?

Zhao: I collected the dinnerware.

Q: You collected dinnerware.

Zhao: Right.

Q: Anything else?

Zhao: I greeted customers. I can do that too.

Q: So you greeted customers.

Zhao: Right, I welcomed them.

Q: Do you like coming to work?

Zhao: I do.

Q: What do you like to do most at work?

Zhao: Washing...I forgot.

Q: What job do you do best?

Zhao: Job...wiping tables, collecting dinnerware. Wiping tables...

Q: That's awesome, you are doing great.

Zhao: Yeah.

Q: Did the customers say good things about you?

Zhao: They did.

Q: What did they say?

Zhao: "Zengzeng Zhao, you listen very well."

$\mathrm{Q}$ : Who do you listen to?

Zhao: I listen to the manager on duty.

Q: Does he tell you what to do?

Zhao: He does.

Q: Do you do the same things every day?

Zhao: Right, the same every day.

Q: Do you ever forget how to do them?

Zhao: I don't forget.

(A co-worker walked past).

Zhao (introducing the co-worker politely): That is my co-worker.

Q: Oh.

Zhao: My co-worker is very nice to me.

Q: How is she nice?

Zhao: She really cares about me.

Q: Do you like everyone?

Zhao: I like my co-workers and the manager on duty. And Pan and Qu really care about me.

Q: How do you show them that you like them? Do you tell them? 
Zhao: I tell them that I will behave.

Q: How will you behave?

Zhao: I will get things done, like wrapping knives and forks, and folding snack boxes.

Q: Your mom must be really happy to see you doing so well.

Zhao: My mom is happy. I don't have a dad anymore. My dad died of lung cancer. My parents and my sister all care very much about me. I have a younger sister and she works. My mom cares about me a lot.

Q: How does your mom care for you?

Zhao: She cares for me every day...My mom cried because she was sad about my dad. I went with my mom to Anhui...(inaudible) I went to Anhui. My dad went into a grave because he died.

Zhao: I don't have any grandparents left either.

Q: So it's just your mom and you girls.

Zhao: Right, just my mom, me and my sister.

Q: How do you usually play with your sister?

Zhao: Usually...My sister gets mad and hits me.

Q: She must have been kidding around with you.

Zhao: She was.

Q: Why did your sister hit you?

Zhao: When I was young, I threw things around. I also hit my co-workers from behind.

Q: Do you still do it?

Zhao: Not anymore. Now I behave. The manager told me to be good and to listen well to Pan. My mom said I am good and took me with her when she had a meeting at the company.

Q: So both your mom and your co-workers said you are doing great.

Zhao: Right, my co-workers say good things about me. And Zheng cares about me too.

Q: So you don't get mad now. What do you do if you get upset?

Zhao: They call my mom if I get upset.

Q: Did your mom come?

Zhao: She did.

Q: But not often, right?

Zhao: Not often. My mom has to work and she has no time.

Q: You have days off. What do you do on Sundays?

Zhao: On Sundays, I take it easy at home, watch TV, and go out for fun or to eat.

On my mom's birthday, I took her out to eat.

Q: You took your mom out to eat?

Zhao: Right.

Q: Then who picked the place to eat?

Zhao: My sister picked the place.

Q: Is the calculator on the table at home for you to use?

Zhao: No, not for me. My sister uses it.

Q: Where do you like to go for fun? 
Zhao: Parks. My mom tells me to go out for fun, which means she cares for me. I must support my mom.

Q: What do you do when you are with your sister?

Zhao: I don't have good memory...I can't remember.

Q: Thank you. That's all for today. You probably need to go back to work.

Zhao: It's okay. Why don't you have some water.

(After the lunch break, Zengzeng Zhao came out of the VIP room and sat down to chat with the observers. She cuddled against the older observer and rubbed the observer's arm).

Q: Do you write every day during lunch break?

Zhao: Yes.

Q: Do you like doing it?

Zhao: Yeah, I like writing.

Q: What do you write?

Zhao: You won't get it.

Q: Does your mom not look at what you write?

Zhao: Neither my mom nor my sister look at it. My mom uses the Internet. My sister uses the Internet, watches TV shows, and listens to music.

Q: So you write for your eyes only?

Zhao: Right.

Q: What kind of music do you like listening to?

Zhao (rubbing the older observer's arm): All kinds. You must be tired. I am very touched that you came for the interview. You are a busy person.

Q: I came today specifically to see you and your co-workers.

Zhao: Our manager on duty is arriving soon.

Q: The lady in black this morning must be the manager on duty.

Zhao: Right. There is another manager, Mr. Zhou. He will be here anytime now.

Q: How do you know?

Zhao: He comes to work at 3:30. We are getting busy now. It gets very busy at night.

(After the day's work and before clocking out, Zengzeng Zhao sat next to the observers and held onto the older observer's arm while nestling against her).

Zhao (looking wronged): The manager was mad at me. ${ }^{7}$

Q: Why? What did you do to make the manager mad at you?

Zhao: He got mad at me and that was mean.

Q: Was there a reason?

Zhao: I (inaudible)...I was mopping the floor.

Q: You were mopping the floor and the manager got mad at you?

Zhao: Right. Nothing happened and he just got mad at me.

Q: I see.

Zhao: Then the manager called my family and talked to my mom.

\footnotetext{
${ }^{71}$ Zengzeng Zhao had expressed her displeasure to the manager on duty about the observer interviewing other employees at the store. But at this time, the observer was as yet unaware of it.
} 
Q: What did your mom tell you?

Zhao: My mom didn't tell me anything.

Q: Did you finish everything you needed to do?

Zhao: I did.

Q: How about doing something extra next time?

Zhao: Okay.

Q: You are very capable. I saw you mopping the floor and taking out the trash. You are the only one cleaning the break room. Do you have to wipe all of the tables, chairs, and the door?

Zhao: All of them. And the backdoor too.

Q: Have you had dinner yet?

Zhao: I have. I had lunch and dinner in one meal.

Q: Will you have dinner again after you get home?

Zhao: Not after I get home.

Q: You don't have to work now?

Zhao: I will keep you company. I don't have any work to do now.

Q: No work? Thank you. In the morning, I saw you taking out a packet with a knife and fork. What's that for?

Zhao: For a delivery order.

Q: You wrapped so many packets. Were they all used today?

Zhao: Yes.

Q: So you will wrap more tomorrow?

Zhao: Tomorrow is my day off.

Q (laughing): Right, tomorrow is your day off.

Q: How many days a week do you have off?

Zhao: Two days.

Zhao: I want to keep you company.

Q: But you are getting off work soon.

Zhao: Not yet. I get off at 7:30, so I still have $1 \mathrm{~h}$.

(It was close to 7:20 at that time).

Q: How do you know what time it is?

Zhao: The time is over there.

Q: I don't see it. Where's the clock?

Zhao: There's a clock.

Q: What sauce did you refill this morning?

Zhao: The yellow sauce.

$\mathrm{Q}$ (pointing to the sauces on the table): Is there a yellow sauce among the three sauces here?

Zhao: There is.

Q: In which bottle?

Zhao: The farthest one contains the yellow sauce.

$\mathrm{Q}$ : So the garlic sauce is called yellow sauce, right?

Zhao: Right.

Q: Thank you for teaching me.

Zhao (laughing): I can call you “elder sister". 
Q (laughing): I am auntie to you. You can clock out now.

Zhao: Right.

Q (checking time on cell phone): Yeah you can, it's 7:30 already.

Zhao: 7:30 already. (Hurrying to get up and leave).

Q: Bye.

\section{Observation of Zengzeng Zhao at Work}

Observation date: 10:30-19:30, July 15, 2016

Observation place: Restaurant where Zengzeng works

Observers and writers: Mei Liao and Zian Li

\begin{tabular}{|c|c|c|}
\hline Time & What Zengzeng Zhao did & Remarks \\
\hline \multirow[t]{2}{*}{ 10:07 } & Refilled sauces & $\begin{array}{l}\text { The observers arrived at 10:07. Zengzeng } \\
\text { was already at work. } \\
\text { Zengzeng opened big cans of ketchup and } \\
\text { Thousand Islands salad dressing and } \\
\text { transferred them to big buckets and sauce } \\
\text { bottles }\end{array}$ \\
\hline & $\begin{array}{l}\text { Talked with co-workers } \\
\text { Left the snack station to look for work } \\
\text { badge } \\
\text { Didn't find badge and returned to snack } \\
\text { station to continue working } \\
\text { Refilled sanitizer }\end{array}$ & $\begin{array}{l}\text { A co-worker realized that Zengzeng } \\
\text { wasn't wearing her badge } \\
\text { Co-worker: Where's your badge? } \\
\text { Zhao: I can't find it } \\
\text { Co-worker: Let's make another one for } \\
\text { you } \\
\text { Zhao: I don't want to pay for it. (It's } \\
\text { actually free.) }\end{array}$ \\
\hline \multirow[t]{2}{*}{ 10:16 } & Delivered sanitizer to the dining area & $\begin{array}{l}\text { Passed the observers and said politely, } \\
\text { "Please wait a bit and I will get some } \\
\text { water for you." }\end{array}$ \\
\hline & $\begin{array}{l}\text { Returned to the non-dining area and } \\
\text { carried water to the dining area }\end{array}$ & $\begin{array}{l}\text { Delivered the glasses of water to the } \\
\text { observers with both hands and said, } \\
\text { "Please have some water." }\end{array}$ \\
\hline 10:18 & $\begin{array}{l}\text { Returned to the non-dining area, took out } \\
\text { small sauce boxes for takeout orders, } \\
\text { filled the boxes with sauces, closed the } \\
\text { boxes and put them aside. Work speed } \\
\text { was an average } 10 \text { s per box }\end{array}$ & \\
\hline 10:24 & $\begin{array}{l}\text { A co-worker found her badge and put it } \\
\text { on for her }\end{array}$ & \\
\hline $10: 38$ & $\begin{array}{l}\text { Finished work for the morning and was } \\
\text { interviewed }\end{array}$ & $\begin{array}{l}\text { Tidied up before leaving the non-dining } \\
\text { area, while a co-worker straightened her } \\
\text { apron for her, smiling and apparently in a } \\
\text { good mood }\end{array}$ \\
\hline
\end{tabular}


(continued)

\begin{tabular}{|c|c|c|}
\hline Time & What Zengzeng Zhao did & Remarks \\
\hline 11:03 & $\begin{array}{l}\text { Returned to the non-dining area to wrap } \\
\text { disposable knives and forks before } \\
\text { putting them in a plastic box and } \\
\text { delivering the box to the dining area }\end{array}$ & \\
\hline $11: 28$ & $\begin{array}{l}\text { Continued wrapping disposable knives } \\
\text { and forks in the non-dining area }\end{array}$ & \\
\hline $11: 32$ & $\begin{array}{l}\text { Put the wrapped knives and forks in a } \\
\text { plastic bag which was then delivered to } \\
\text { the dining area }\end{array}$ & $\begin{array}{l}\text { Dining area co-worker: Are you done } \\
\text { with wrapping? } \\
\text { Zhao: Yes } \\
\text { Dining area co-worker: Please take them } \\
\text { to the cashier in the front. Thank you }\end{array}$ \\
\hline $12: 36$ & $\begin{array}{l}\text { Went to the soda station to fetch a } \\
\text { ketchup bottle for filling up sauce boxes } \\
\text { for takeout orders }\end{array}$ & $\begin{array}{l}\text { Passed the observers and said politely, } \\
\text { "Please wait a bit" which was } \\
\text { accompanied by a hand gesture }\end{array}$ \\
\hline $12: 39$ & $\begin{array}{l}\text { Used up the ketchup in the sauce bottle } \\
\text { and fetched a big bucket to refill the bottle }\end{array}$ & $\begin{array}{l}\text { As of that moment, she had finished all of } \\
\text { her fixed work for that day. She would } \\
\text { spend the rest of the day helping out } \\
\text { co-workers or resting }\end{array}$ \\
\hline $15: 25$ & Lunch break & $\begin{array}{l}\text { Carried a white bag into the VIP room, } \\
\text { took out paper and started writing with } \\
\text { head tilted. Wrote two to three lines on } \\
\text { each piece of paper } \\
\text { Observers: Are you practicing writing? } \\
\text { Zhao: I am } \\
\text { Observers: What are you writing? } \\
\text { Zhao: I don't know. I don't want to tell } \\
\text { you }\end{array}$ \\
\hline 16:02 & $\begin{array}{l}\text { Organized her bag and left the VIP room. } \\
\text { Sat next to the observers and leaned } \\
\text { against the older observer with an } \\
\text { intimate air }\end{array}$ & $\begin{array}{l}\text { Spoke first, then only spoke by way of } \\
\text { answering questions }\end{array}$ \\
\hline $16: 10$ & Returned to the non-dining area & \\
\hline $16: 35$ & $\begin{array}{l}\text { Talked to the manager on duty in front of } \\
\text { the break room while several co-workers } \\
\text { looked on }\end{array}$ & $\begin{array}{l}\text { Everyone looked serious and Zengzeng } \\
\text { Zhao didn't look happy }\end{array}$ \\
\hline $17: 58$ & $\begin{array}{l}\text { Found the floor mop and got ready to mop } \\
\text { the floor in the break room }\end{array}$ & \\
\hline 19:02 & Took out trash from the break room & \\
\hline 19:15 & $\begin{array}{l}\text { Sat next to the observers and held onto } \\
\text { the arm of the older observer with an } \\
\text { intimate air }\end{array}$ & $\begin{array}{l}\text { Spoke first, then only spoke by way of } \\
\text { answering questions }\end{array}$ \\
\hline 19:30 & Left for the day & \\
\hline
\end{tabular}

Translated by Cissy Zhao

Edited by Andy Boreham and Zijian Chen 
Open Access This chapter is licensed under the terms of the Creative Commons AttributionNonCommercial-NoDerivatives 4.0 International License (http://creativecommons.org/licenses/bync-nd/4.0/), which permits any noncommercial use, sharing, distribution and reproduction in any medium or format, as long as you give appropriate credit to the original author(s) and the source, provide a link to the Creative Commons license and indicate if you modified the licensed material. You do not have permission under this license to share adapted material derived from this chapter or parts of it.

The images or other third party material in this chapter are included in the chapter's Creative Commons license, unless indicated otherwise in a credit line to the material. If material is not included in the chapter's Creative Commons license and your intended use is not permitted by statutory regulation or exceeds the permitted use, you will need to obtain permission directly from the copyright holder.

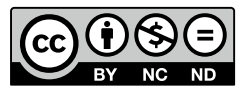

